\title{
Pengaruh Pemberian Alpukat terhadap Kadar Kolesterol LDL Darah pada Mahasiswa/i Obesitas di Fakultas Kedokteran Universitas HKBP Nommensen Medan Tahun 2019
}

\author{
Komandaniel Simanullang ${ }^{1}$, Joseph Partogi Sibarani ${ }^{2}$, Dessy Harianja ${ }^{3}$ \\ ${ }^{1}$ Mahasiswa, Fakultas Kedokteran Universitas HKBP Nommensen \\ 2 Departemen IImu Penyakit Dalam Fakultas Kedokteran Universitas HKBP Nommensen \\ ${ }^{3}$ Departemen IImu Forensik Fakultas Kedokteran Universitas HKBP Nommensen \\ Korespondensi: Komandaniel Simanullang, Email: komandaniel07@gmail.com
}

\begin{abstract}
Background: Low Density Lipoprotein (LDL) is a lipoprotein that contains more cholesterol. High levels of blood LDL cholesterol are associated with obesity and increased of risk factor of cardiovascular disease. Avocado (Persea americana) is a well known and popular fruit in society. The active ingredient (omega 9-oleic acid) of avocados can be use to decrease LDL cholesterol levels and increase HDL (High Density Lipoprotein) cholesterol levels in blood in order to reduce the risk factor of cardiovascular disease.
\end{abstract}

Objective: This study aims to determine the effect of avocado consumption on blood LDL cholesterol levels in obese students in Medical Faculty of Universitas HKBP Nommensen.

Method: This study used a pre-experimental design one group pretest and posttest study. Subjects were 20 obese students of Medical Faculty of Universitas HKBP Nommensen and selected by simple random sampling technique. For the first 14 days, samples are given dietary intervention and the next 14 days given dietary intervention and avocado juice. Measurement of LDL cholesterol levels was done before and after 14 days given avocado juice. Data analysis used paired T test to analyze differences in blood LDL cholesterol levels before and after being given avocado juice.

Results: The results are average value of blood LDL cholesterol levels on pretest was $137.1 \mathrm{mg} / \mathrm{dL}$ and posttest was $128.25 \mathrm{mg} / \mathrm{dL}$ with mean reduction was $8.85 \mathrm{mg} / \mathrm{dL}$. Paired T test analysis shows that the avocados effect to blood LDL cholesterol is significantly influenced with value of $p=0.036(p<0.05)$.

Conclusion: There is an effect of avocado consumption on blood LDL cholesterol levels.

Keywords: Avocado (Persea americana), LDL cholesterol, obesity

\begin{abstract}
Abstrak
Latar belakang: Low Density Lipoprotein (LDL) merupakan lipoprotein berdensitas rendah yang lebih banyak mengandung kolesterol. Tingginya kadar LDL darah berkaitan dengan kondisi obesitas dan peningkatan risiko penyakit kardiovaskular. Alpukat (Persea americana) merupakan buah yang sudah sangat dikenal dan digemari masyarakat. Kandungan aktif (omega 9-asam oleat) dalam buah alpukat dapat membantu menurunkan kadar kolesterol LDL (Low Density Lipoprotein) dan meningkatkan kadar kolesterol HDL (High Density Lipoprotein) dalam darah yang akan menurunkan risiko penyakit kardiovaskular.
\end{abstract}

Tujuan: Penelitian ini bertujuan untuk mengetahui pengaruh pemberian alpukat terhadap kadar kolesterol LDL darah pada mahasiswa/i obesitas di Fakultas Kedokteran Universitas HKBP Nommensen. 
Metode: Penelitian ini menggunakan desain pre-experimental one group pretest posttest study. Subjek penelitian adalah 20 mahasiswa Fakultas Kedokteran Universitas HKBP Nommensen yang mengalami obesitas dan dipilih dengan teknik simple random sampling. Untuk 14 hari pertama diberi intervensi diet dan 14 hari berikutnya diberi intervensi diet ditambah dengan jus alpukat. Pengukuran kadar kolesterol LDL dilakukan sebelum dan sesudah 14 hari diberikan jus alpukat. Analisis data menggunakan uji T berpasangan untuk menganalisis perbedaan kadar kolesterol LDL darah sebelum dan sesudah diberikan jus alpukat.

Hasil: Hasil penelitian didapati nilai rerata kadar kolesterol LDL pretest adalah 137,1 mg/dL dan posttest adalah $128,25 \mathrm{mg} / \mathrm{dL}$ dengan penurunan rerata sebesar $8,85 \mathrm{mg} / \mathrm{dL}$. Hasil analisis uji T berpasangan didapati bahwa pemberian alpukat terhadap kolesterol LDL darah berpengaruh secara signifikan dengan nilai $p=0,036(p<0,05)$.

Kesimpulan: Terdapat pengaruh pemberian alpukat terhadap kadar kolesterol LDL darah.

Kata Kunci: Alpukat (Persea americana), kolesterol LDL, obesitas

\section{Pendahuluan}

Alpukat (Persea americana) merupakan buah yang sudah sangat dikenal dan digemari oleh masyarakat. Kandungan utama dalam buah alpukat adalah karotenoid, asam lemak, mineral, phenolic, phytosterol, protein dan vitamin. ${ }^{1}$ Alpukat diketahui memiliki khasiat sebagai antioksidan, antidiabetik dan efek hipolipidemik. Mekanisme hipolipidemik alpukat terutama mempengaruhi penyerapan lemak makanan dan transportasi kolesterol. ${ }^{1,2}$

Berbagai penelitian sudah dilakukan untuk mencari bahan hipolipidemik yang berasal dari alam, salah satunya alpukat. Penelitian sebelumnya menunjukkan bahwa alpukat memberi perbaikan signifikan terhadap kadar kolesterol. Penelitian yang dilakukan oleh Wijayanti dkk. pemberian jus alpukat terhadap tikus putih jantan (Rattus novergicus) menunjukkan bahwa pemberian jus alpukat dapat mempengaruhi penurunan kadar kolesterol. ${ }^{3}$ Penelitian pada manusia yang dilakukan oleh Sahrul Rahman menemukan bahwa pemberian jus alpukat menunjukkan penurunan kadar kolesterol LDL dan peningkatan kadar kolesterol HDL secara bermakna. ${ }^{4}$ Namun menurut penelitian Hiya A. Mahmassani dkk, pemberian alpukat tidak memberikan efek yang signifikan terhadap penurunan kadar kolesterol LDL dalam serum. ${ }^{5}$

Low Density Lipoprotein (LDL) merupakan lipoprotein berdensitas rendah yang mengandung protein dalam jumlah sedikit dan kolesterol yang lebih banyak. Kolesterol yang diangkut oleh LDL paling sering disebut sebagai kolesterol "jahat" karena akan diangkut ke dalam sel, termasuk sel endotel yang melapisi lumen pembuluh darah. Peningkatan kadar kolesterol LDL dalam plasma dapat menyebabkan peningkatan jumlah kolesterol yang teroksidasi serta terbentuknya radikal bebas ${ }^{6,7}$ Kadar kolesterol LDL yang meningkat dalam plasma (>100 mg/dl) dapat mengakibatkan timbulnya plak aterosklerotik di lumen endotel pembuluh darah yang disebut aterosklerosis. Penimbunan plak aterosklerotik secara bertahap dapat menyebabkan penyempitan lumen pembuluh darah yang nantinya dapat berakibat pada pasokan darah ke jantung dan ke organ lainnya menjadi berkurang. Kolesterol LDL juga menjadi faktor risiko timbulnya penyakit jantung koroner dan stroke. ${ }^{7}$

Obesitas merupakan salah satu faktor risiko yang dikaitkan dengan peningkatan kolesterol LDL dalam darah. ${ }^{8}$ Overweight/obesitas bisa disebabkan oleh peningkatan konsumsi makanan padat energi yang mengandung lemak tinggi dan aktivitas fisik yang kurang. Pada tahun 2016, World Health Organization (WHO) melaporkan lebih dari 1,9 miliar orang dewasa (usia $>18$ tahun) mengalami overweigth (dengan indeks massa tubuh $\geq 25 \mathrm{Kg} / \mathrm{m} 2$ ), dari angka tersebut 650 juta adalah obesitas. ${ }^{9}$ Pelajar dan mahasiswa, termasuk mahasiswa kedokteran beresiko tinggi terhadap obesitas. ${ }^{10}$ Menurut penelitian Anitha M. dkk di Sri Balaji Vidyapeeth University, prevalensi obesitas berdasarkan pedoman Asia-Pasifik pada mahasiswa kedokteran berusia 20-25 tahun adalah sebesar $2 \%-2,5 \%$ dan overweight sebesar $4 \%-4,5 \%$. Mahasiswa cenderung makan lebih sedikit buah dan sayuran setiap hari serta asupan tinggi lemak dan kalori tinggi. Perilaku diet mahasiswa sering ditandai dengan melewatkan jam makan, konsumsi makanan cepat saji, dan sering ngemil. ${ }^{10,11}$

Peningkatan kadar kolesterol LDL dapat dicegah dan ditatalaksana melalui modifikasi faktor risiko, seperti pola hidup sehat, pencegahan dan pengobatan medis, maupun obat penurun kolesterol.12,13 Sehubungan dengan hal tersebut, banyak penelitian di lakukan untuk menemukan obat hipolipidemik dari alam, salah satunya alpukat.

Untuk mengetahui pengaruh pemberian alpukat terhadap kadar kolesterol LDL darah pada mahasiswa/i obesitas di Fakultas Kedokteran Universitas HKBP Nommensen tahun 2019.

\section{Metode}

Penelitian ini menggunakan metode penelitian pre-experimental dengan desain one group pretest posttest study. Sebanyak 20 mahasiswa Fakultas Kedokteran Universitas HKBP Nommensen Medan yang mengalami obesitas pada tahun 2019 diikutsertakan menjadi subjek dalam penelitian ini. Cara pengambilan sampel dilakukan dengan teknik simple random sampling. Subjek yang dipilih merupakan mahasiswa yang bersedia ikut dalam penelitian dengan menandatangani informed consent, tidak alergi terhadap alpukat, dan tidak memiliki gejala klinis yang mengarah pada penyakit sistemik.

Penelitian ini dilakukan selama 28 hari di Fakultas Kedokteran Universitas HKBP Nommensen Medan. Pada 14 hari pertama subjek diberikan intervensi diet, dan 14 hari berikutnya diberikan intervensi diet dan ditambah dengan konsumsi alpukat dalam bentuk jus. Jus yang diberikan mengandung 200 gram buah alpukat, dengan volume air sebanyak $50 \mathrm{~mL}$ sebagai pelarut. Pengkuran kadar kolesterol LDL darah hanya dilakukan sebelum 
dan sesudah pemberian jus alpukat selama 14 hari dan dilakukan di Laboratorium Klinik Thamrin Medan.

Analisis univariat dilakukan untuk mengetahui karakteristik subjek berdasarkan umur, jenis kelamin, dan IMT (Indeks Massa Tubuh). Uji hipotesis menggunakan uji T berpasangan untuk melihat jumlah subjek yang mengalami penurunan kadar kolesterol LDL. Sebelumnya dilakukan uji normalitas Shapiro-Wilk untuk melihat distribusi data. Penurunan kadar kolesterol LDL dianggap bermakna jika nilai $p<0,05$.

\section{Hasil}

Tabel 1 menunjukkan gambaran karakteristik subjek berdasarkan umur, jenis kelamin, dan IMT. Pada tabel 1 dapat dilihat bahwa subjek dalam penelitian ini lebih banyak berusia antara 17-25 tahun dengan sebanyak 19 subjek (95\%), berjenis kelamin laki-laki sebanyak 13 subjek (65\%), IMT antara 30-34,9 sebanyak 17 subjek (85\%), dengan rerata kadar kolesterol LDL darah sebesar $(131,1 \mathrm{mg} / \mathrm{dL})$.

Tabel 1. Karakteristik Subjek Penelitian Berdasarkan Umur, Jenis Kelamin dan IMT

\begin{tabular}{|c|c|c|c|}
\hline Subjek & $\begin{array}{c}\text { Frekuensi } \\
\text { (n) }\end{array}$ & $\begin{array}{l}\text { Persentase } \\
(\%)\end{array}$ & $\begin{array}{c}\text { Rerata } \\
\text { Kadar } \\
\text { Kolesterol } \\
\text { LDL } \\
\text { (mg/dL) }\end{array}$ \\
\hline \multicolumn{4}{|l|}{ Umur } \\
\hline 17-25 tahun & 19 & 95 & \multirow{9}{*}{137.1} \\
\hline 26-35 tahun & 1 & 5 & \\
\hline \multicolumn{4}{|l|}{ Jenis Kelamin } \\
\hline Laki-laki & 13 & 65 & \\
\hline Perempuan & 7 & 35 & \\
\hline \multicolumn{3}{|c|}{ Indeks Massa Tubuh } & \\
\hline $30.0-34.9$ & 17 & 85 & \\
\hline $35.0-39.9$ & 2 & 10 & \\
\hline$>40$ & 2 & 5 & \\
\hline Total & 20 & & \\
\hline
\end{tabular}

Dari penelitian yang telah dilakukan mengenai pengaruh pemberian alpukat terhadap kadar kolesterol LDL darah pada mahasiswa/i obesitas diperoleh hasil sebagai berikut:

Table 2. Kadar Kolesterol LDL Sebelum dan Sesudah Pemberian Alpukat

\begin{tabular}{lccc}
\hline Kadar Kolesterol LDL & $\begin{array}{c}\text { Rerata } \\
(\mathrm{mg} / \mathrm{dL})\end{array}$ & SD & p value \\
\hline Pre-test & 137.10 & 49.93 & 0.036 \\
Post-test & 128.25 & 42.35 & 0 \\
\hline
\end{tabular}

\section{Pembahasan}

Berdasarkan hasil dari pengukuran kadar kolesterol LDL darah subjek pada penelitian ini, didapatkan bahwa perbedaan antara kadar kolesterol LDL darah pretest dan posttest. Hasil pengukuran rerata kadar kolesterol LDL darah subjek menunjukkan bahwa nilai posttest $(128,25 \mathrm{mg} / \mathrm{dL}$ ) lebih rendah dibandingkan dengan pretest $(137,1)$ yang berarti menunjukkan penurunan kadar kolesterol LDL darah yang signifikan $(p<0,05)$ setelah pemberian alpukat.
Hasil penelitian ini sesuai dengan penelitian yang dilakukan oleh Shahrul Rahman, yang menunjukkan pemberian buah alpukat menunjukkan penurunan kadar kolesterol LDL yang signifikan.1,4 Didukung dengan penelitian sebelumnya terhadap tikus putih jantan yang dilakukan oleh Wijayanti dkk. serta penelitian yang dilakukan oleh Hartadiyanti, menunjukkan penurunan kadar kolesterol LDL dan peningkatan kadar kolesterol HDL yang signifikan. ${ }^{3}$

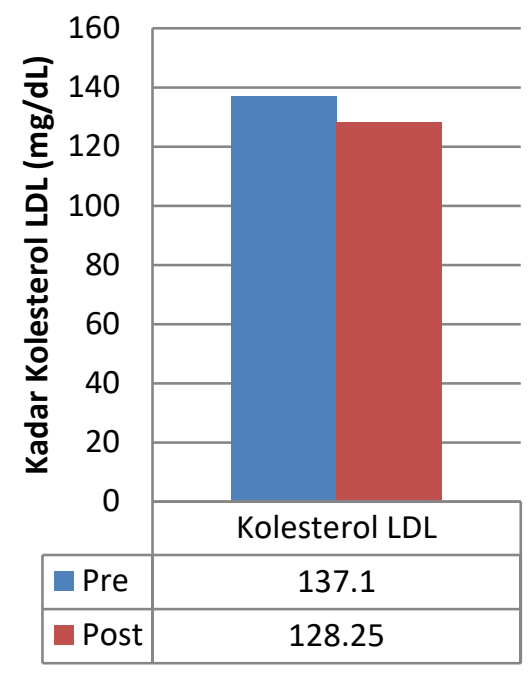

\section{Gambar 1. Grafik Kadar Kolesterol LDL Sebelum dan Sesudah Pemberian Alpukat}

Penurunan kadar kolesterol LDL kemungkinan disebabkan oleh diet rendah kolesterol yang diberikan kepada subjek dan senyawa dalam buah alpukat, terutama omega- 9 asam oleat serta kandungan bahan aktif lainnya seperti vitamin, serat, dan asam kolesterol lainnya yang diduga dapat membantu metabolisme dalam tubuh.1,4,14,15 Selama 14 hari sebelum pemberian alpukat, subjek diminta untuk diet rendah kolesterol dengan tidak mengonsumsi makanan tinggi kolesterol seperti seafood, kuning telur ayam, otak sapi, telur burung puyuh, jeroan, makanan bersantan, keju nabati, dan susu kedelai. Diet rendah kolesterol ini dibantu dengan kandungan omega-9 asam oleat dalam alpukat yang dapat menyebabkan disposisi lemak dalam tubuh menjadi tertekan, serta mempertahankan fungsi reseptor LDL di permukaan sel sehingga mampu mempercepat siklus pengambilan kolesterol dari sirkulasi. Selanjutnya kolesterol LDL dari sirkulasi akan lebih banyak masuk ke dalam sel hati sehingga kadarnya dalam sirkulasi akan menjadi turun. Vitamin C dalam alpukat juga mempunyai efek untuk membantu reaksi hidroksilasi dalam pembentukan asam empedu sehingga meningkatkan ekskresi kolesterol dan menurunkan kadar kolesterol dalam darah. Selain vitamin $C$, ada juga vitamin $A$ dan vitamin $E$ yang juga berfungsi sebagai antioksidan dalam sirkulasi. 1,4,15.

\section{Kesimpulan}

Pemberian jus alpukat yang dibarengi dengan diet rendah kolesterol dapat berpengaruh pada penurunan kadar kolesterol LDL darah mahasiswa/i obesitas di Fakultas Kedokteran Universitas HKBP Nommensen Medan. 


\section{Ucapan Terima Kasih}

Peneliti mengucapkan terima kasih kepada Universitas HKBP Nommensen dan pihak Laboratorium Klinik Thamrin Medan yang telah memberikan kesempatan serta memfasilitasi peneliti untuk melakukan dan menyelesaikan penelitian ini.

\section{Daftar Pustaka}

1. Rahman S. Effect of Avocades to LDL Cholesterol as a preventive risk of atherosclerosis. Int J Multidiscip Curr Res. 2019;7(1):4-7

2. Tabeshpour J, Razavi BM, Hosseinzadeh H. Effects of avocado (Persea americana) on metabolic syndrome: a comprehensive systematic review. Phyther Res. 2017; 31(6):819-837

3. Wijayanti, Yulina, Elliya R. Pengaruh pemberian jus alpukat (Persea Americana Mill) terhadap penurunan kolesterol tikus putih jantan (Rattus Novergicus) galur Wistar Kota Bandar Lampung Tahun 2014. J Kesehat Holistik. 2014;8(3):147-52.

4. Rahman S. Studi pendahuluan pengaruh alpukat terhadap profil lemak di poli penyakit dalam Klinik Iman. Dep IImu Penyakit Dalam Fak Kedokt Univ Muhammadiyah Sumatera Utara Medan, Indones. 2018;7(1):1-9.

5. Mahmassani HA, Avendano EE, Raman G, Johnson EJ. Avocado consumption and risk factors for heart disease: a systematic review and meta-analysis. Am Soc Nutr. 2017;107:523-36.

6. Adam J. Dislipidemia. In: Sudoyono A, Setiyohadi B, Alwi I, Simadibrata M, Setiati S, editors. Buku Ajar IImu Penyakit Dalam Jilid II. VI. Jakarta: Interna Publishing; 2016. p. 1985-92.
7. Sherwood L. Fisiologi Manusia Dari Sel ke Sistem. 8th ed. Yesdelita N, editor. Jakarta: EGC; 2014.

8. Knowing Your Risk for High Cholesterol [Internet]. 2019 [cited 2019 Jul 4]. Available from: https://www.cdc.gov/cholesterol/risk_factors.htm

9. World Health Organization. Obesity and overweight [Internet].. 2019 [cited 2019 Jul 4]. Available from: https://www.who.int/news-room/factsheets/detail/obesity-and-overweight

10. Ashok C, Karunanidhi S. Prevalence of overweight and obesity among young female college students in Chennai city. J Obes Metab Res. 2016;3(1):23-31

11. M A, E MR, Dm M, J CK. Prevalence of obesity and overweight among medicos in both male and female student. Asian J Pharm Clin Res. 2016;9(3):289-91

12. Preventing High Cholesterol [Internet]. CDC. 2017 [cited 2019 Jul 4]. Available from: https://www.cdc.gov/cholesterol/prevention.htm

13. Managing High Cholesterol [Internet]. CDC. 2017. Available from: https://www.cdc.gov/cholesterol/managing-cholesterol.htm

14. Karina A. Khasiat dan Manfaat Alpukat. I. Surabaya: Setomata; 2012

15. Wardani YAK. Potential of avocado (Persea americana mill) to reduce coronary heart disease risk. Agromed Unila. 2014;1(1):55-60. 